\title{
Effect of Brain-Based Learning Strategies on Secondary School Students' Academic Achievement in Federal Capital Territory, Abuja, Nigeria
}

\author{
Angela Orengwu Okatahi, Hosea Abalaka Apeh and Omolara Ayoka lyiegbuniwe \\ Department of Educational Foundations \\ Faculty of Education, University of Abuja, Abuja, Nigeria \\ Corresponding Author: hosea.apeh@uniabuja.edu.ng
}

\begin{abstract}
The study was on the effect Brain-Based Learning Strategies on the academic achievement of secondary school students in Abuja, Nigeria. The pretest post-test Quasi Experimental Research design was used with a sample of 142 Senior Secondary School Students drawn from two schools. Two intact classes were randomly selected from each school. Data for the study was sourced using the Economics Achievement Test (EAT). The hypothesis was tested at a significant level of 0.05 using ANCOVA. The findings revealed a significant difference in the academic achievement with mean difference of 15.82 in favor of the Experimental Group. The study concluded that Brain-based learning strategies have significant effect on students' academic achievement as the result indicated that the effect of the treatment, (brain-based learning strategy) was significantly positive on students' academic achievement in Economics. The study recommended that teachers should adopt the Brain-based learning strategies in teaching Economics by providing a relaxed environment with low threat, good nutrition, physical exercise, movement, drama, drinking of water before and during lessons.
\end{abstract}

Key Words: Academic Achievement, Brain-Based Learning Strategies, Conventional Teaching Method

\section{Introduction}

While the purpose of education is to develop cognitive abilities and thinking power of students, the outcome of a teaching-learning activity depends on how the learners perform and interact with the information or experience gained in the process of learning. The essence of formal education is measured in terms of the academic achievement that accrues to the learners which leads to a change in orientation and disposition of learners towards life.

Nigerian education sector has not been able to achieve the desired educational status. Evidence abounds in the results of the 2010 to 2018 West Africa Senior Secondary Schools Certificate Examinations in Nigeria, which reveal fluctuations in the performance of candidates that sat for the examinations. Five subjects were used as benchmark because the requirement for admission into any school in Nigeria is to have credits and above in a minimum of five subjects including English Language and General Mathematics. The three other subjects are specific for the area of choice whether Arts, Science, Humanity or Commercial (Federal Ministry of Education-Basic and Secondary Education Dept. 2018).

Table 1: Analysis of WASSCE results from year 2010 to 2018

\begin{tabular}{llllllllll}
\hline Year & 2010 & 2011 & 2012 & 2013 & 2014 & 2015 & 2016 & 2017 & 2018 \\
\hline Credit pass \% in 5 subjects & 24.94 & 29.11 & 38.81 & 36.57 & 31.28 & 38.68 & 52.97 & 59.22 & 49.98 \\
\hline
\end{tabular}

While it is obvious that more needs to be done to make teaching and learning more effective, several studies have established a link between the instructional strategy adopted by the teachers and students' academic achievement. According to Adunola (2011), for instance, there is a link between poor academic performance by majority of students and application of ineffective teaching methods. 
The study further lamented that teachers in Nigerian public schools today were comfortable using the conventional teaching method which has led to poor academic achievement by students in most subjects.

Although, lecture method is effective in delivering knowledge to a large number of students as well as covering a wide range of topics within a short time, it involves students receiving information mainly through input given by teachers in the classrooms. This, however, hinders students' innate learning potentials and ignores their individual differences leading to poor performance.

Since learning is to affect a change in the learner, there is need for intellectual improvement in learners in order to foster intellectual development. Rowland (2010) opined that learners need to interact directly with their world through discourse and hands-on experiences with peers and adults. Therefore, creating a stimulating and conducive environment will make learning take place naturally (Jensen, 2000). If teachers design learning environments that allow each learner process information and form knowledge based on their individual differences and abilities, learning will be more interesting and productive. Smilkstein (2003) stated that although the brain is innately able to facilitate learning, the knowledge, skills, or concepts the brain acquires by means of its innate learning process depends on the learner's experience and the environment. For this reason, research on cognitive neuroscience (Giedd, 2008 \& Farnsworth, 2018) based on findings on the structure and functionality of the brain, has emphasized a braincompatible instructional method, which is also known as brain-based learning.

Brain-Based Learning (BBL) is a student-centered learning approach that utilizes the whole brain and considers the different learning styles preferred by the students. It takes care of students' individual differences for effective and lasting learning (Kinach, 2010) and is more concerned with 'how' learning takes place rather than 'what' is learnt. When the learning environment is designed to allow each learner process information and form knowledge based on their individual differences and abilities, learning becomes more interesting and contextual.

Brain-based learning proposes a shift in instructional approach from focus on the teacher to the learner for effective learning to occur. It involves active participation of students in constructing their own knowledge in diverse learning situations and contexts (Caine \& Caine, 1999). Brain-based learning strategies aim at maximizing the functional ability of the brain in a conducive environment. Stevens and Goldberg (2001) stated that, applying brain research to instructional design result in the practice of braincompatible instruction instead of brain-antagonistic instruction.

Neuroscientists have established that brain function can be affected by factors such as diet, stress, learners' emotional state, environments, quality of sleep, music, color, oxygen, movement, exercise, serotonin and water intake (Immodino-Yang, 2011). Brain-based learning strategies are motivated by the general belief that learning can be accelerated and improved if educators base how and what they teach on the science of learning rather than on past educational practices, established conventions or assumptions about the learning process.

For better understanding and application of the brain-based learning strategy, some of the proponents of the strategy, Caine and Caine (2000) developed twelve basic facts that guide brain-based learning approach. The principles include: 1- The brain /mind is social, 2- learning is physiological, 3the search for meaning is innate, 4- the search for meaning occurs through "patterning", 5- Emotions are critical to patterning, 6- the brain/mind processes wholes and parts simultaneously, 7learning involves both focused attention and peripheral perception, 8- Learning always involves conscious and unconscious procedures, 9- learning is developmental, 10- the brain understands and remembers when facts and skills are embedded in natural spatial memory, 11- learning is enhanced by challenges and inhibited by threat, 12- Every brain is uniquely organized.

Furthermore, there are three instructional conditions for learning as indicated below:

Orchestrated Immersion: This involves ensuring that students concentrate on concepts being learnt; teachers should relate concepts to real life situations while learners have to use their memory to explore the content that is characterized with holistic and correlative native (Caine \& Caine, 2002). Abstract concept in Economics like production, location and localization of industry, for instance, can be made vivid by going on field trips to create a real-life scenario.

Relaxed Alertness: This involves eliminating all manner of fear in the learners while preserving 
highly challenging environments. This optimal state of mind emphasizes that the learners should feel secure so that they can take a risk (Caine \& Caine, 2011). Therefore, teachers need to organize the class to ensure all manner of fear is removed from the classroom (Gozuyesil \& Dikicl, 2014; Thomas \& Swamy, 2014). This can be done by using art or music in lesson presentations.

Active Processing: This means allowing the learner to process information by internalizing and consolidating the information. Duman (2010) opined that learners with active brains achieve meaningful learning through memory work that relates new objects to the ones already existing in the cognitive structure. This can be accomplished when teachers can give break in between the lesson, encourage movement and allow water intake to enable space for connection and reflecting (Caine \& Caine, 2000).

Brain-based learning strategies stimulate the whole brain for effective function, which results in greater academic progress. Research in neuroscience has established that each brain is wired differently just as each fingerprint is distinct from the others (Jancke, 2018). Each person's brain is able to detect patterns, memorize, self-correct, learn from experience and create knowledge. Therefore, as long as the brain is not prohibited from fulfilling its normal processes, learning will occur naturally (Wilson, 2018).

Despite research findings on how the brain perceives, processes, stores and retrieves information, which is important to guide the pedagogy, it is unfortunate that many schools in the Federal Capital Territory from the researcher's observation continue to promote practices in line with the lecture method. The lecture method involves students receiving information mainly through input given by teachers in the classrooms with little or no learners' involvement in the entire learning process. This method however, is effective in delivering knowledge to a large number of students and covering a wide range of topics within a stipulated time. As such, each teacher becomes more comfortable with the lecture method at the expense of participatory approaches which can result into meaningful learning.

The lecture method gives little or no attention to the importance of students' knowledge base and the ability to apply such knowledge effectively, rather its' focus is on the number of topics (syllabus content) the teacher is able to cover within a given timeframe. Most teachers using lecture method only succeed in lumping information on students rather than facilitating a learning process that would help learners acquire, assimilate and exhibit good knowledge of the subject. There is remarkable difference between the meaning that is gained when one memorizes material and the meaning one achieve when one gains a good grasp of the concept learned. While memorizing is fantastic and helps one learn the intended information, a lack of understanding of the learning material implies that one has learnt absolutely nothing. The difference between memorizing information and understanding information is like a mathematics student who memorized all the equations without a clue on how to use them to solve the problems. With memorization, the learner recalls the equations and with understanding he is able to apply the equation. Therefore, memorizing and understanding go hand in hand.

Wachob (2018) suggests that, in addition to teaching strategies, there should be a focus on good learning strategies, which will help the students to improve upon their assimilation of the subject matter, to have a deeper understanding of the concepts, as well as to retain acquired knowledge for suitable usage. This suggests a shift from the teacher to the learner for effective learning to occur. Brain-based learning offers a brain-friendly strategy devoid of the teacher-centeredness, traditional authoritative attitude of teachers, learning by cramming and verbatim reproduction of educational concepts as given in textbooks.

The brain-based learning strategy ensures learner's emotional state is taken care of by adopting the use of music, art and jokes to create a relaxed learning environment which encourages learners to freely express themselves by contributing to the learning process actively Hardiman (2001). Furthermore, neuroscientists have established that brain function can be affected by factors such as diet, exercise, stress and learners' emotional state (ImmodinoYang, 2011). Desautels (2016) buttressed this by explaining that, 'buried deep in the brain limbic system is an emotional switching station called the amygdala and it is here that our human survival and emotional messages are subconsciously prioritized and learned'. This is opposed to the lecture method, which operates a formal learning environment, which requires students to be quietly seated and listen to the teacher, the only custodian of knowledge to deliver the information while the 
learners remain passive, as little or nothing is required of them during the lesson.

Learning activities such as group projects, group discussions or role play provide learners in the brain-based learning classrooms opportunities to develop positive social interaction among their peers. This helps to boost their self-confidence and makes them appreciate their individual competence through team work. Learners are also required to drink minimal water before and intermittent sips through lessons as their body requires reducing the rate of dehydration which could lead to stress (Hans, 2018). This practice is totally opposed to the traditional classroom practice, where acts such as drinking water, eating or any form of movement is seen as a form of distraction and its punishable as it is strictly against the rules.

To ensure that the outlined topics for the term is covered, learning activities which help students conceptualize and internalize learned concepts such as role play, group discussions, individual expression and excursions are employed in the brain-based learning classroom to relate concepts to real life situation and help students learn better in a relaxed but challenging environments (Jensen, 2000). These are hardly used at all in the traditional classroom. Jokes are also employed in the brain-based learning classroom to encourage active processing.

Academic achievement has long been recognized as one of the important goals of education. It is the extent to which a student, teachers or the institution have achieved their short or long-term educational goals (Ratsogi, 2012). The academic achievement of a student is seen in this study as individual progress and improvement in terms of acquired knowledge, skills and competences.

Phillip et al. (2008) expressed academic achievement or academic performance as the extent to which a student, teachers or the institution have achieved their short or long-term educational goals. Academic success and achievement in every society represents accomplishment of the education system in targeting the right objectives and paying due attention to gratification of individual needs (Tamanayee et al., 2011). Therefore, an education system is considered efficient only when academic achievement of its students at all levels is the greatest and the highest.
Vaghese and Pradya (2016) conducted a study to investigate effectiveness of brain-based learning on academic achievement, study habits and stress of students at the secondary school level in India. Findings revealed improvement in learners' academic achievement when brain-based learning was adopted. Francis (2014) in a study on the effectiveness of brain-based learning strategy on academic achievement in Economics by secondary school students also established a positive relationship between brain-based learning strategies and improvement in students' academic achievement. Haghighi (2013) conducted a study to investigate the effect of brain-based learning in sophomore students in aircraft repair and maintenance on academic achievement and retention and reported a positive relationship between brain-based learning and learners' academic achievement. From the previous studies, the researchers observed that the consensus seem to be that students taught using Brain-based learning strategies (BBLS) recorded better academic achievement and higher level of knowledge retention compared to students taught using other traditional methods. It was also established that Brain-based learning strategies reduced students' stress, improved students' attitude toward learning and motivated learners to learn because students were allowed to take charge of their learning and form knowledge from existing information. Despite these known advantages, the researchers wondered why Brain-Based learning is generally unheard off in the study area. This necessitated the conduct of the present study.

Teachers can implement a brain-based education by designing the classroom and presenting lessons to suit the knowledge of how the brain functions while considering the three conditions of learning as illustrated in Figure 1.

The brain-based learning input-process-output (BBLIPO) chart illustrates the pathway to enhance the brain function. Effective learning is achievable when the learners are not just present in the classroom but are emotionally active and relevant to the learning process. The brain-based learning strategy is hinged on the three conditions for learning, namely Relaxed Alertness, Orchestrated Immersion and Active Processing which requires the introduction of activities (input) that enhance brain function in order to achieve effective learning (output) (Caine \& Caine, 2000). 


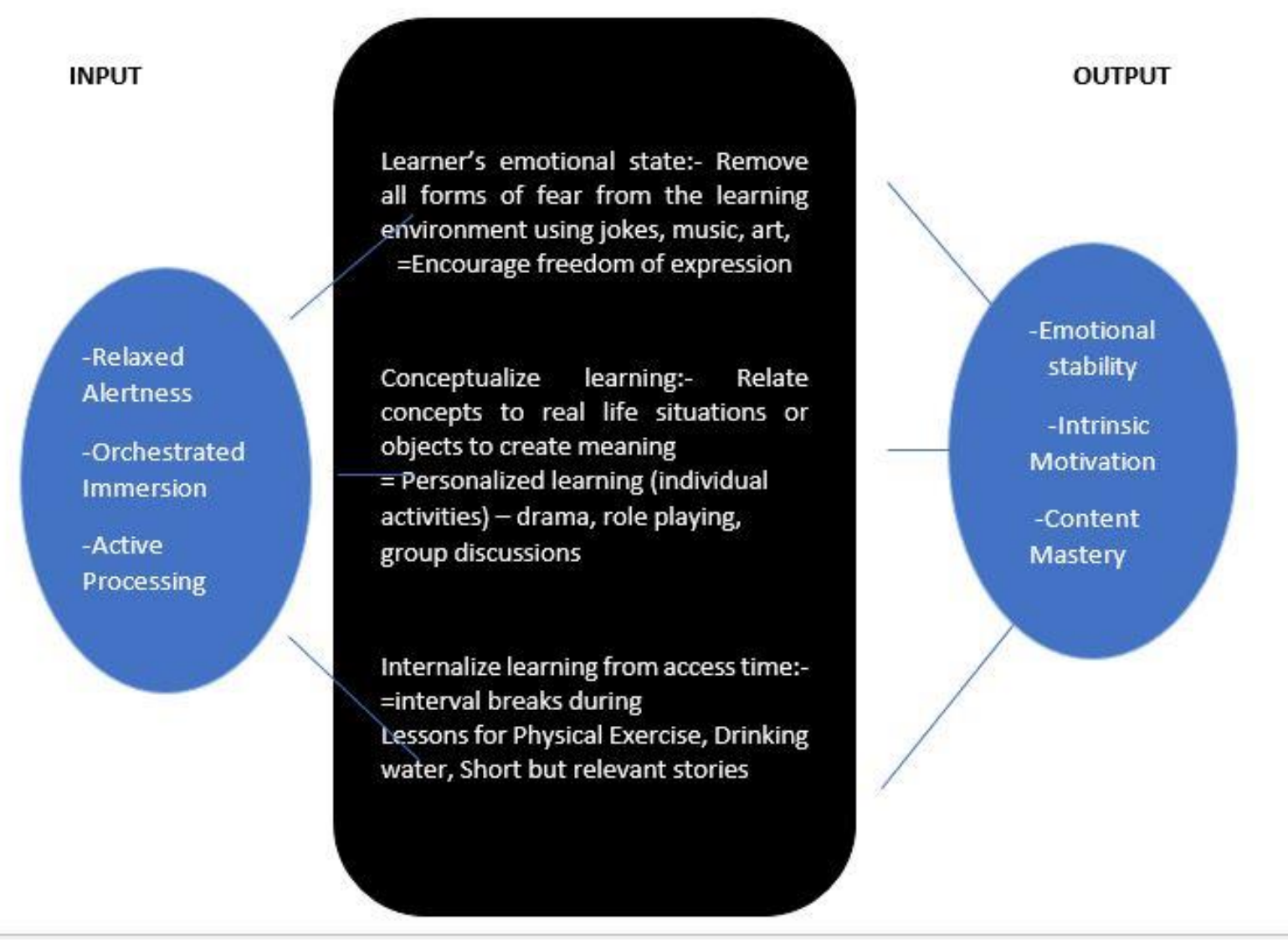

Figure 1: Brain-Based Learning Input-Process-Output Chart

Brain-based Learning Strategies (Caine \& Caine, 2000) and the Integrated Thematic Instruction (ITI) have emanated from two different fields but have strong similarities in their implications for education. Both theories connect learning to a synergy between the body and the brain. Kovalik's ITI theory incorporates much of the current researches on brain-based learning (Kovalik \& McGeehan, 1999). Its principles considered not only the individuality of learners but also other important components of affective learning such as learners' health, environment, absence of threat, respect and pattern making. The ITI and BBL educational environments translate abstract concepts to real life scenarios.

In spite of the findings of brain-based learning and its relevance in improving academic achievement of students, a review of available empirical studies on BBL and students' academic achievement reveals that there is need to conduct a similar study in the Federal Capital Territory, Nigeria in order to provide empirical support for any policy review to promote the use of Brain-Based learning Strategies in schools within the study area. An additional gap from existing literature is the fact that many of the existing related studies have concentrated on the sciences and languages while the present study focused on Economics as a social science subject.

The present educational system in Nigeria emphasizes on memorization rather than thinking (Malu, 2010), even though the crux of education is to develop cognitive and thinking abilities of learners by facilitating a learning process that will enable learners to acquire, assimilate and process good knowledge in various subjects. The researchers in this study were curious to find out if a change in instructional strategy from a teacher-centered approach to a student-centered approach by applying brain-friendly strategies would have any effect on secondary school students' academic achievements in the Federal Capital Territory. The study was guided by the following research questions:

1. What is the difference in pre-test mean achievement scores of students taught Economics using brain-based learning 
strategies (experimental group) and students taught Economics using conventional lecture methods (control group)?

2. What is the difference in post-test mean achievement scores of students taught Economics using brain-based learning strategies and students taught Economics using conventional lecture?

The two research questions called for testing of the following null hypothesis:

$\mathrm{H}_{01}$ - There is no significant difference in pre-test and post-test mean achievement scores of students taught Economics using brain-based learning strategies and those taught Economics using conventional lecture methods.

\section{Research Methodology}

This section explains the methodology that guided this study. It addresses the research design, the population and sampling procedures, instruments for the study, validity and reliability, experimental procedures and statistical treatment of data.

\section{Research Design}

The research design for the study was the pre-test post-test, control group design in a quasiexperimental setting. For this study, the researcher used two classes, one class for each of the two selected schools. One class represented the experimental group while the other class represented the control group.

\section{Population and Sampling}

The target population for this study comprised 16,894 students in Senior Secondary I in all the public Senior Secondary Schools in Abuja Municipal Area Council of the Federal Capital Territory that offer Economics as a subject. The sample size for the study comprised 142 senior secondary one (S.S.1) students from two selected senior secondary schools. In a quasi-experiment, the sample is considered adequate to allow for ease of control over the variables. Often, too few subjects are used to make it possible to detect a significant effect. More so, the intact classes were used. Having selected two schools for the control and experimental group, the available number of students in each class was used. The two coeducational senior secondary schools were randomly selected using the simple random sampling technique. The two selected schools were randomly assigned to the experimental group and control group. The experimental group had seventy (70) students while the control group had seventytwo (72) students.

\section{Instruments for the Study}

The instrument used for the study was the Economics Achievement Test (EAT) to measure students' academic achievement in Economics. Economics Achievement Test (EAT) comprised of 50 multiple choice test items adapted from West African Secondary School Certificate Examinations past questions from the year 2010 to 2018. Items were selected based on the topics that were taught to students during the 10 weeks such as: Activities of marketing boards in Nigeria, Mining, Financial Institutions, Money, and Distributive Trade. These topics were drawn from the National Economics curriculum for Senior Secondary School students published by the Nigerian Educational Research and Development Council (NERDC). There were two versions of Economics Achievement Test (EAT), the pre-test version and post-test version; both versions contained same items but reshuffled to ensure same item was assigned different numbers in order to disguise the instrument.

\section{Validity and Reliability}

The Economics Achievement Test (EAT) was derived from the West African Examinations Council whose test items were standardized and could be judged valid as far as content, coverage and syllabus is concerned. However, for content and coverage, EAT was still subjected to a table of specification (Table 2). For face validity, the Economics Achievement Test (EAT) was given to experts in the field of education for scrutiny. The rating by the experts after observation, corrections and final consideration served as logical validity of the instruments.

For reliability of instrument, the EAT was subjected to pilot test using 31 students ( 18 male students and 13 female students) in a Government Secondary School within the FCT. The students were taught Economics topic "Theory of Productivity" for two weeks. At the completion of the two weeks, EAT was re-administered to the students and the scripts were marked and recorded.

The method of reliability thus used is the test-retest method. The reliability co-efficient was established using Kuder-Richardson formula. Kuder-Richardson formula 20 is applicable when each question is 
either right or wrong. The reliability co-efficient of good enough to judge the instrument reliable.

0.78 was obtained for the EAT. This was considered

Table 2: The Table of Specification

\begin{tabular}{|c|c|c|c|c|c|c|}
\hline SN & Content & Knowledge & Comprehension & Application & Items & $\%$ \\
\hline 1 & $\begin{array}{l}\text { Activities of Marketing Boards in Nigeria: } \\
\text { Provision of fertilizers, provision of } \\
\text { seedlings, formation of co-operative } \\
\text { societies, provision of improved storage } \\
\text { facilities, provision of extension services }\end{array}$ & 27 & 30 & & 2 & 4 \\
\hline \multirow[t]{2}{*}{2} & Mining & & & & & \\
\hline & $\begin{array}{l}\text {-Components of the Nigerian Mining } \\
\text { Industry } \\
\text {-Minerals; types, uses and location }\end{array}$ & $45,35,5$ & $33,37,48$ & $36,46,49$ & 9 & 18 \\
\hline \multirow[t]{4}{*}{3} & Financial Institutions: & & & & & \\
\hline & - Meaning and types of financial & $11,22,24$ & $16,18,43$ & $10,44,23$ & 20 & 40 \\
\hline & institutions & $25,26,34$ & $6,12,14,21$ & 1,3 & & \\
\hline & $\begin{array}{l}\text {-Money and Capital markets } \\
\text {-Benefits of the capital market }\end{array}$ & 13,18 & & & & \\
\hline \multirow[t]{2}{*}{4} & Money: & & & & & \\
\hline & $\begin{array}{l}\text {-Definition and historical development } \\
\text {-Barter Trade and its deficiencies } \\
\text {-Types of Money } \\
\text {-Functions of Money } \\
\text {-Characteristics of Money }\end{array}$ & $15,19,50$ & $2,9,28$ & $7,32,40$ & 9 & 18 \\
\hline \multirow[t]{3}{*}{5} & Distributive Trade: & & & & & \\
\hline & $\begin{array}{l}\text {-Channels/ chain/ process of distribution } \\
\text {-Wholesalers-- Roles in distribution } \\
\text {-Retailers-- Roles in distribution } \\
\text {-Roles of co-operative societies } \\
\text {-Roles of government agencies } \\
\text {-Problems of middlemen in distribution in } \\
\text { Nigeria-Ways of improving the system of } \\
\text { distribution of goods in Nigeria }\end{array}$ & $4,17,41$ & $8,31,42,47$ & $20,29,39$ & 10 & 20 \\
\hline & Total & 18 & 18 & 14 & 50 & 100 \\
\hline
\end{tabular}

\section{Experimental Procedure}

The procedure began with a pre-test where a version of the instrument was administered to the participants to establish their initial status before the commencement of treatment. The treatment tool for the experiment was the lesson plan designed using the 12 principles of brain-based learning strategies and the three conditions of learning (relaxed alertness, orchestrated immersion and active processing) developed by Caine \& Caine (2001) and the lesson plan for the conventional lecture method. The lesson plan for the two groups was prepared by the researcher for consistency in lesson presentation for the groups. The researcher drafted the following teacher's guidelines for the study based on the principles of Brain-based learning strategies (BBLS).

1. A balanced diet chart was displayed in the classroom and teachers informed learners before the lessons about the importance of nutrition and hydration to their brain development and function.

2. Teachers encouraged students to come with drinking water in their water bottles, which students took during the lessons to maintain body hydration and reduce stress.

3. Teachers, during the first lesson enlightened students on the importance of food intake to their physical development and the consumption of water for good brain health 
and function in accordance with Hans (2018) and Wilson (2013).

4. Diagrams used in learning some concepts and most group assignments were displayed in the classroom.

5. Students were encouraged to reflect on previous knowledge.

6. Teachers created a stimulating environment to take care of students' emotion using means such as: playing soft or classical music on few occasions, cheerful environment through brain energizers and sarcasm free jokes.

7. Students were motivated using praise or positive adjectives chosen by each student as a prefix to their names, for example Intelligent Henry, Smart Adamu, Charming Sochi; this really boosted students' selfesteem.

8. Concepts were broken down to manageable parts to enable students internalize them easily and form meaning.

9. Classes were broken into groups using various formats such as birth months, first alphabet of name, number of siblings, etc. This was to encourage peer interaction and learning. The groups engaged in group discussions, projects and role playing; thereafter students were allowed to evaluate themselves across groups without criticism.

10. Teachers encouraged students to freely express their fears, confusions and ideas as regards each module of topic taken.

11. Teachers generated friendly environments by encouraging smiles and laughter, through teacher's friendly attitude towards students and physical exercise.

12. Students were encouraged to form their own patterns as they learn; the teachers did this by posing questions that inspire curiosity in students or allow time for reflection on new information. This promoted critical thinking and subsequently presentation of meaningful contents by merging new ideas into existing ones.

13. Students were encouraged to perform individual task of their choice as it relates to learning concepts.

14. Innovations were appreciated and ambiguities acknowledged.

The experimental group was taught by the researchers led by a team member who is an Economics teacher while the control group was taught by the school Economics teacher with the researcher as observers based on the school management arrangement. The post-test version of Economics Achievement Test (EAT) was administered to the two groups at the ten (10) weeks of study to assess the basic knowledge of Economics attained after treatment.

The Economics Achievement Test lasted for one (1) hour and the scripts were marked and the scores recorded. The scoring was done thus: 1mark obtainable for each test item $=1 \times 50=50$ equivalent to $100 \%$. Each participant's score was then converted to $100 \%(n / 50 \times 100)$; where $n=$ no of correct answers.

\section{Statistical Treatment of Data}

The data collected were analyzed using statistical tools, namely, means, standard deviation, ANCOVA. The Statistical Package for Social Sciences (SPSS) software (Version 25) was used to compute the data collected.

\section{Findings and Discussion}

The results were presented using tables according to research questions and were subsequently interpreted.

\section{Research Question One}

What is the difference in pre-test mean achievement scores of students taught Economics using brain-based learning strategies (experimental group) and students taught Economics using conventional lecture methods (control group)?

Table 3: Mean Achievement Score and Standard Deviation

\begin{tabular}{llll}
\hline Group & $\mathrm{N}$ & Mean & Std. Dev. \\
\hline Control & 72 & 29.19 & 9.61 \\
Experimental & 70 & 27.16 & 10.59 \\
\hline
\end{tabular}

The result presented in Table 3 reveals a difference in the mean achievement scores of the students in the Experimental and Control group before the treatment was administered. There was a higher mean score in Economics for students in the Control Group at pre-test with $($ mean $=29.19, \mathrm{SD}=9.61$ ), 
compared to that of students in the Experimental Group with (mean $=27.16, \mathrm{SD}=10.59)$. This result implies that the mean achievement score of students in the control group is slightly higher than the mean achievement score of students in the experimental group before each group was taught Economics using conventional lecture method and Brain-based learning strategies respectively.
Conventional lecture method was in use before the intervention.

\section{Research Question Two}

What is the difference in post-test mean achievement scores of students taught Economics using brain-based learning strategies and students taught Economics using conventional lecture?

Table 4: Mean Achievement Score and Standard Deviation at Post-test

\begin{tabular}{llll}
\hline Group & $\mathrm{N}$ & Mean & Std. Dev. \\
\hline Control & 72 & 34.31 & 9.76 \\
Experimental & 70 & 48.51 & 13.93 \\
\hline
\end{tabular}

The result presented in Table 4 reveals a difference in the mean achievement scores of the students in the Experimental and Control Group after the treatment was administered. There was a higher mean score in Economics for students in the Experimental Group at post-test (mean $=48.51$, SD $=13.93$ ), compared to that of students in Control Group with (mean = 34.31, SD = 9.76).

This result implies that the mean achievement score of students in the Experimental group is higher than the mean achievement score of students in the Control group after both groups were taught Economics using Brain-based learning strategies and conventional lecture method respectively.

Therefore, the brain-based learning strategy has positive effect on students' academic achievement based on the fact that, the achievement of students in the experimental group was better at post-test compared to their counterparts in the control group with a mean difference of 14.21 in favor of students in the experimental group.

The study tested the following null hypothesis:

$\mathrm{H}_{01}$ - There is no significant difference in pre-test and post-test mean achievement scores of students taught Economics using brain-based learning strategies and students taught Economics using conventional lecture methods.

Table 5 shows the Analysis of Covariance comparing the post-test mean achievement scores of students taught Economics using brain-based learning strategies and those taught using lecture method while controlling for covariant (pre-test). There was significant difference in the mean achievement score between the experimental and control groups with $F(1,139)=54.58, p=0.000$. The null hypothesis $\mathrm{H}_{0} 1$ was therefore Rejected.

Table 5: Analysis of covariance (ANCOVA) Result of Difference in Pre-test and Post-test Mean Achievement Scores of Students taught Economics using Brain-Based Learning and Lecture Method

\begin{tabular}{lllllll}
\hline Source of variations & Sum of squares & df. & Mean squares & $\mathrm{F}$ & Sig & Decision \\
\hline Corrected Model & 7438.350 & 2 & 3719.175 & 27.624 & .000 & \\
Intercept & 21075.595 & 1 & 21075.595 & 156.541 & .000 & $\mathrm{~S}$ \\
Covariate (pre-test) & 272.747 & 1 & 272.747 & 2.024 & .157 & NS \\
Treatment (groups) & 7348.840 & 1 & 7348.840 & 54.584 & .000 & $\mathrm{~S}$ \\
Error & 18714.016 & 139 & 134.633 & & & \\
Total & 268476.000 & 142 & & & & \\
Corrected Total & 26152.366 & 141 & & & & \\
\hline
\end{tabular}

The study findings suggest that, the brain-based learning strategies have positive (significant) effect on post-test achievement scores of students when covariant effect (pre-test) was controlled. This result revealed that the application of brain-based learning strategies in the learning of Economics accounted for the difference in post-test mean achievement scores of the students. The researchers conclude that, there is no significant difference between students taught Economics using brain-based learning strategies and students taught using conventional lecture method before the treatment was administered to the groups. However, after intervention, it was found that the treatment, brainbased learning strategy used in the experimental group was significantly positive on students' 
academic achievement in Economics. It revealed that the brain-based method of instruction produced a significant effect on the post-test achievement scores of students when compared with measure effect derived from the control group using conventional teaching methods.

\section{Discussion of Findings}

The findings in this study revealed that students who were taught Economics using the Brain-based learning strategies (student-centered method) had higher scores in the post-test than the students taught using conventional lecture method (teachercentered method). The results from the analysis indicated that the treatment, Brain-based learning strategies that was used in the experimental group had more positive effect on students' academic achievement. The results revealed that the Brainbased learning strategies produced a significant effect on the post-test mean achievement scores of students. This indicated that the treatment, Brainbased learning strategies (BBLS) accounted for the difference in students' mean achievement scores at post-test. This could be attributed to the implementation of some Brain-based learning strategies such as, a exposure to highly challenging learning environment with absence of threat in the classroom which made students relate freely with their peers and teachers as well as developing positive emotional associations with fellow students and becoming more actively involved in their learning. The findings of this study in relation to the mean achievement scores of students in the experimental and control groups supported empirical related reviewed literatures such as Mekarina and Ningsih, (2017), Jack and Kyado (2017), Vaghese and Pradya (2016), Olaoluwa and Ayantoye (2016), and Adebayo (2005) with affirmations that the positive mean gain in mean achievement scores of students taught using Brainbased learning is connected to the implementation of Brain-based learning strategies in the learning process. These findings also support Jensen (2000) who opined that nature's biological imperative is simple: no intelligence or ability will unfold until or unless it is given the appropriate model environment as demonstrated by the principles of Brain-based learning strategies. In addition, Wortock (2002) opined that Brain-based learning strategies improve critical thinking success. The learning activities of Brain-based learning provided the highly challenging and low threat environment that enhanced students' self-confidence. This enabled students to connect learning materials with real-life. Incorporating of health-related factors such as physical exercises, stress management activities, encouraging students to drink water before and during lessons and observing 1-2 minutes breaks after 20-25 mins of learning allowed active processing which helped students form meaning on their own hence improved their learning outcomes.

\section{Conclusion and Recommendations}

This study concluded that Brain-based learning strategies have significant effect on students' academic achievement. This is because there was significant difference in the achievement mean scores of students taught Economics using brainbased learning strategies and the students taught using the conventional lecture method. This result indicated that the effect of the treatment, (brainbased learning strategy) used in the experimental group was significantly positive on students' academic achievement in Economics. It revealed that the method of instruction produced a significant effect on the post-test achievement scores of students.

Based on the conclusions, the following recommendations are put forward. First, teachers should ensure to provide a relaxed environment with low threat and high challenging environment in order to ensure that learning environment is stressfree. This would enhance effective learning and improve learning outcomes. Teachers should encourage good nutrition, physical exercise, movement, sarcasm free jokes, art (music), drama, drinking of water before and during lessons.

Secondly, Economics teacher in the Federal Capital Territory should apply the Brain-based learning strategies because of its relevance in improving learners' achievement.

\section{Reference}

Adebayo, P. (2005). Brain-based instructional strategy and students' learning outcomes in chemistry in Ibadan, Nigeria. M.Ed. Dissertation. University of Ibadan, Nigeria.

Adunola, O. (2011). An analysis of the relationship between class size and academic performance of students. Ego Booster Books, Ogun State, Nigeria.

Caine, G., \& Caine, R. N. (1999). Making connections: Teaching and the human brain. 
Alexandria, Virginia, Association for Supervision and Curriculum Development.

Caine, G., \& Caine, R. N. (2000). The learning community as a foundation for developing teacher leaders. NASSP Bulletin, 84, (616), 27-34.

Caine, G., \& Caine, R. N. (2001). The brain, education, and the competitive edge. Lanham, MD: Scarecrow Press.

Caine, G., \& Caine, R. N. (2002). Making connections: Teaching and the human brain. Menlo Park, CA: Addison-Wesley.

Caine, G., \& Caine, R. N. (2011). How new research on learning is re-writing how schools work and teachers teach. Learning Landscapes, 5 (1), 19- 25 .

Desautels, L. (2016). Brain based learning: Brains in pain cannot learn. Retrieved May 14th, 2019, from www.Shutterstock.com/Rawpixel.com.

Duman, B. (2010). The effects of brain-based learning on the Academic Achievement of students with different learning styles. Eric Journal of Education Sciences, 10 (4), 2077-2103.

Federal Ministry of Education (2018). Analysis of WASSCE results from year 2010 to 2018Basic \& Secondary Education Department. Retrieved on 21/01/2020 from https://education.gov.ng/wpcontent/uploads/2019/10/WAEC_RESULTS_ STATISTICS_2016-2018.pdf

Farnsworth, B. (2018). EEG vs MRI vs fMRI - what are the differences? Retrieved on May 12th, 2019, from https://imotions.com/ blog/eeg-vs-mri-vs-fmri-differences/

Francis, F.T. (2014). Effectiveness of brain-based learning strategy on emotional regulation and critical thinking of higher secondary school students. PhD Thesis submitted to Department of Education, Bharathiar University. Retrieved on 20/07/2019 from http://hdl.handle.net/10603/93420.

Giedd, J. (2008). The teen brain: Insights from neuroimaging. Journal of Adolescent Health, 42 (4), 335-343.
Gozuyesil, E. \& Dikici, A. (2014). The effect of brainbased learning on academic achievement: A Meta-analytical Study. Educational Sciences: Theory \& Practice. 14(2): 642-648

Haghighi, M. (2013). The effect of brain-based learning on Iranian EFL learner's achievement and retention. Procedia - Social and Behavioural Sciences. 70, 508- 516.

Hans, V. (2018, May 21). Study of the day: mild dehydration alters mood, makes thinking hard. The Atlantic. Retrieved on 20/07/2019 from https://www.theatlantic. com/health/archive/2012/02/...dehydrati.../ 253320/

Hardiman, M. M. (2001). Connecting brain research with dimensions of learning. Educational Leadership. 59 (3), 52-55.

Immordino-Yang, M. (2011). Implications of affective and social neuroscience for educational theory. Educational Philosophy and Theory, 43 (1), 98-103.

Jack, G. U. \& Kyado, J. J. (2017). Effectiveness of brain-based learning strategy on students' academic achievement, attitude, motivation and knowledge retention in electrochemistry. Journal of Education, Society and Behavioural Science. 21 (3) 1-13.

Jancke, L. (2018). Every individual has a unique brain anatomy, study reveals. Retrieved on 20/07/2019 from https://neurosciencenews.com/uniquebrain-anatomy-9541/

Jensen, E. (2000). Brain-based learning: A reality check. Educational Leadership, 57 (7), 76-80.

Kinach, B. M. (2010). A review of "how the brain learns Mathematics. The Journal of Educational Research, 103:5, 368-369.

Kovalik, S. J. \& McGeehan, J. R. (1999). Integrated Thematic Instruction (ITI): from brain research to application in Reigeluth, C. M. (ED) Instructional-design theories and models, Volume II. Mahwah, NJ: Lawrence Erlbaum Associates.

Malu, A. O. (2010). Universities and medical education in Nigeria. Niger Med J 51:84-8. 
Mekarina, M. \& Ningsih, Y.P. (2017). The effects of brain-based learning approach on motivation and student's achievement in mathematics learning. Journal of Physics: Conf. Series 895 (1), 1-6

Olaoluwa, S. A. \& Ayantoye, C. A. (2016). Impact of brain-based instructional strategy on academic performance of deaf students in mathematics in Oyo School of Handicapped, Nigeria. World Journal of Educational Research. 3(2), 447-459.

Phillip, T., Davis, C, Miller, P., \& Naglieri, J. (2008). Exercise and children's intelligence, cognition and academic achievement. Educational Psychology. 20 (2), 111-131.

Ratsogi, M. A. (2012). Academic achievement: Concept and level of aspiration with academic achievement for high school students. Retrieved on 08/04/2020 from https://shodhganga.inflibnet.ac.in/bitstrea m/10603/35390/17/17_synopsois.pdf

Rowland, D. (2010). The brain that changes itself: Stories of personal triumph from the frontiers of brain science. Journal of Academic Language and Learning, 4(1), B1B3. Retrieved from https://journal.aall.org.au/index.php/jall/art icle/view/121.

Smilkstein, R. (2003). We're born to learn: using the brain's natural learning process to create today's curriculum. California: Corwin Press: A Sage Publications Company.

Stevens, J. \& Goldberg, D. (2001). For the learners' sake. Tucson, Zephyr Press
Tamanayee, F., Mohammad, R. \& Gandomi, Z. (2011). The relationship of achievement motivation with academic achievement in students. Quarterly Journal of Education Strategies, 4(1): 15-

Thomas, B. M. \& Swamy, S. S. (2014). Brain-based teaching approach-A new paradigm of teaching. International Journal of Education and Psychological Research. 3 (2), 62-65.

Vaghese, M. G \& Pradya, A. (2016). A study on the effectiveness of brain-based-learning of students of secondary level on their academic achievement in biology, study habits and stress. International Journal of Humanities and Social Sciences. 5 (2), 103-122.

Wachob, D. A. (2018, January 23). Public school teachers' knowledge, perception, and implementation of brain-based learning practices (Doctoral dissertation, Indiana University of Pennsylvania). Retrieved on 20/07/2019 https://dspace.iup.edu/bitstream/handle/2 069/1908/.

Wilson, L. O. (2018, October 2). The Brain-based education - An overview - The second principle. Retrieved on 20/07/2019 www.thesecondprinciple.com/optimallearning /brainbasededucation-anoverview.

Wortock, J. M. (2002). Brain-based principles applied to the teaching of basic cardiac code to associate degree nursing students using the human patient stimulator. Unpublished Doctorate Thesis. University of South Florida. 